\title{
Application of Remote Sensing Data for Slum Identification Using Geography Information System (Case: Former Harbor, Singaraja City)
}

\author{
Ruhilatul Janah ${ }^{1 *}$, A Sediyo Adi Nugraha ${ }^{1}$ \\ 1 Universitas Pendidikan Ganesha, Indonesia \\ *e-mail: ruhilatul@undiksha.ac.id
}

Article history: Received 15 December 2020; Accepted 31 March 2021; Available online 30 April 2021

\begin{abstract}
This research was conducted in Singaraja City using high-resolution remote sensing images and geographic information systems. The purpose is to use remote sensing images and geographic information systems to identify slum settlements, especially the former harbor area in Singaraja City. Slum settlement is the impact of population growth that is difficult to control. As a result, the remote sensing image can identify three features: slums, non-slum settlement, and non-slum areas. Most slum settlements are located in coastal areas, and non-slum settlements are located in areas close to economic locations and tourist sites and offices. The most significant introduction to slum identification comes from the building area. Based on these results, it can be concluded that slum settlement can be identified through images obtained from Google earth and recognized visually through interpretation keys.
\end{abstract}

Copyright @ Universitas Pendidikan Ganesha. All rights reserved.

\section{Introduction}

Remote sensing is a science that discusses in order to obtain information about object areas or phenomena through data obtained with a tool without direct contact with the object, area, or phenomenon to be studied. Remote sensing imagery has developed for decades especially using satellite vehicles that are capable of monitoring the earth surface at certain time intervals so that it can use to detect changes in land use, Urban Heat Island (UHI), shoreline, and disaster such as drought with vegetation and Land Surface Temperature (Hasan et al., 2019; Indrawati \& Sunarto, 2009; A. S.A. Nugraha et al., 2019; A Sediyo Adi Nugraha, 2019; A Sediyo Adi Nugraha et al., 2019; A Sediyo Adi Nugraha \& Atmaja, 2020; Septiani et al., 2019; Suarjana et al., 2020). Besides, remote sensing is a technology that can overcome data measurement problems for fast and accurate information (Maspiyanti et al., 2013),(A Sediyo Adi Nugraha, 2019). The development of remote sensing technology has now interacted with population development as completeness and data collection accuracy.

Research using remote sensing technology and geographic information systems is an innovative strategy in spatially visualizing the existing problems to produce accurate geospatial information, especially in the population (Dalilah \& Ridwana, 2019a). Remote sensing applications are capable of extracting detailed information because they provide a high enough spatial resolution. This information can be in the form of vegetation coverage, building density, the distance of settlements to main roads and industrial areas, which are some of the 
parameters determining the level of settlement comfort and settlement form (Maru \& Hidayati, 2016), settlement identification through remote sensing is one solution to determine the distribution of settlement conditions due to rapid population growth.

The rapid population growth led to the increasing need to develop uncontrolled settlements, especially in urban areas (Ekartaji et al., 2014). The main factor that causes an area to be categorized as a slum is excessive urbanization from villages to cities. As a result of shifting conflicts between residents. Land change due to population growth is essential for using remote sensing technology. Therefore, the research objective is how the role of remote sensing and geographic information system in identifying slum settlement.

\section{Method}

\section{Study Area}

Singaraja City is one of the cities in Bali Province, precisely in the Buleleng Regency. Buleleng Regency is located in the northern part of Bali island, extending from west to east. Geographically, Buleleng Regency is located at the position of $8^{\circ} 03^{\prime} 40^{\prime \prime}-8^{\circ} 23^{\prime} 00^{\prime \prime}$ South latitude and $114^{\circ} 25^{\prime} 55^{\prime \prime}-115^{\circ} 27^{\prime} 28^{\prime \prime}$ east longitude (BPS Kecamatan Buleleng, 2019). Singaraja city was once the capital of the Province of Bali and Nusa Tenggara and was a shipping center making it the largest single dock on the island of Bali at its time. However, as the government center moved to southern Bali, the former harbor was no longer functioning, and that is one of the tourism locations.

This study uses the former harbor In Singaraja City, Buleleng is a slum settlement study because of the large number of interests outside the region to come to north Bali, former harbor. This location has led to the urbanization of many residents outside Singaraja. Urbanization realized if there is a higher urban population growth rate than rural residents (Christiawan, 2019). Indirectly, slum settlement is due to a decline in the quality of its function as a place to live. The decline in the quality of the functions includes low quality of buildings, not served with adequate environmental infrastructure, and endangering the sustainability of life and livelihoods of its inhabitants (Ilmy \& Budisusanto, 2017).

The remote sensing image used is the January 2020 image obtained from Google Earth Pro. These images have quality and feasibility for use in research because the information taken is in the form of visual features of images such as building shapes. The building shape is necessary to identify as the building existing in the former harbor on the remote sensing image.

GIS is used to identify the visual appearance of remote sensing images. Identification of slum settlements in Ex. Buleleng Pier uses the Quantum-GIS application (QGIS); besides analyzing slum areas, QGIS can create maps and maps with different formats according to their use, allowing QGIS to comprise both raster and vector layers by displaying. This data is in the process of analyzing data and digitizing existing buildings in the former harbor as an identification of a slum surface.

\section{Interpretation Image}

Visual interpretation recognizes objects' spatial characteristics based on an element from remote sensing images (Anaperta et al., 2019). Image interpretation is an activity to study aerial photographs or identify an object and assess its importance. The method used uses the Visual Interpretation method on high-resolution images, using Quickbird imagery, which analyzes it using interpretation elements such as hue color, size, shape, texture, pattern, shadow, site, and object association visible (Suharini, 2007). Research activities to identify existing slum settlements in the former harbor can be identified by the presence of image interpretation elements, how what is on the surface of the earth varies according to the appearance in the image. This research examines settlements to make it easier to identify settlements and non- 
settlements at Former Harbor in Singaraja. As for some of the characteristics of settlements in image data, like: (1) the house is the same shape and size, (2) the longitudinal pattern follows the highway, (3) the distance from one object to another object is the same and (4) the roof color is almost the same. This characteristic makes it easier to distinguish existing buildings and settlements in Ex. Buleleng Pier. In contrast to the characteristics of slum settlements, which have a building pattern which is irregular and tightly laid out with one another, the size of the houses is different, the fragility of buildings between the distance from one object to another is very low, and the more likely densities are clustered and irregular. The slum settlements' roofs mostly use asbestos or zinc, and a small part of the houses' roofs use tiles.

\section{Field Survey}

Field survey activities are carried out after the data processing process is complete; this field survey is a check and validation.

Table 1.

Slum Criteria for Field Survey

\begin{tabular}{|c|c|c|c|c|}
\hline \multirow{2}{*}{ No } & \multirow{2}{*}{\multicolumn{2}{|c|}{ Variable }} & \multicolumn{2}{|l|}{ Criteria } \\
\hline & & & Slum & Not-Slum \\
\hline \multirow[t]{3}{*}{1.} & \multirow[t]{3}{*}{$\begin{array}{l}\text { Field } \\
\text { Survey }\end{array}$} & Building Condition & $\begin{array}{l}\text { Semi-Permanent and Not } \\
\text { Permanent }\end{array}$ & Permanent \\
\hline & & $\begin{array}{l}\text { Environmental } \\
\text { conditions }\end{array}$ & Dirty & Clean \\
\hline & & Layout & $\begin{array}{l}\text { Somewhat Organized, Irregular } \\
\text { Settlements }\end{array}$ & $\begin{array}{l}\text { Organized } \\
\text { Settlements }\end{array}$ \\
\hline
\end{tabular}

Source: (Suharini, 2007)

A table's existence as a material to facilitate field surveys can refer to the variable table above to determine slum settlements and non-slum settlements by taking a field survey to determine what is in the slum and what is no-slums in the ground.

\section{Result and Discussion}

\section{Analysis of Slum}

The slums on the ex, the pier Buleleng, are caused by an imbalance between population growth and urbanization from village to city because cities have many functions that attract people and insufficient housing. With the arrival of the visitors increased the number of people increased and required land populated areas.

Slum identification in the former harbor has three features: slum settlements, non-slum settlements, and non-settlements (Table 2). The slum settlement in area 1 (Figure 2.a.) shows that the location is in a coastal area where most of the population is fishermen. Slum settlements have an unmonitored distance from the main road from the location of economic activity so that the area that is visible in front is an area with non-slum settlement conditions because some are used as the economic sector. The interpretation proves that remote sensing technology helps identify slum areas compared to being done manually and not based on existing spatial data (Dalilah \& Ridwana, 2019b).

The appearance of slum settlements in area 2 (Figure 2.b.), predominantly dominated by the appearance of non-slum settlements, has the same characteristics, namely being in coastal areas and activities in fishers. The difference is in area 2, where the residential area close to the tourism sector shows a more orderly and orderly form of settlement. The difference is because 
the people who live between the eastern and western regions are racially different. In the western region, it is more dominated by migrant residents from Java, and in the eastern region is dominated by migrant or mixed residents from China who have long lived in the region.

This condition shows that settlement provides information related to slum settlements and provides the population's characteristics in an area. Furthermore, looking at the complete difference, it is easy to identify between slum settlements and non-slum settlements. Most slum settlements have less than 60 square meters $(\mathrm{m} 2)$ and non-slum settlements $>60 \mathrm{~m} 2$, where it is seen in the roof that reflects the buildings.

The overall study area in the identification of slum settlements is shown in Figure 3. The development of slum settlements is mostly influenced by the majority of activities such as fishing and labor. In comparison, areas as public locations such as fields, parks, economic centers, and industry are surrounded by non-slum settlements. The criteria for non-residential areas are used only as strategic locations for economic activity and tourist and office locations. Usually, the former harbor of Buleleng is the hub, where slums dominate to the west of the former Buleleng pier, and some of the non-housing and settlements are to the south and east of the former harbor.

Table 2.

Building Area Based on Building in Former Harbor

\begin{tabular}{|c|c|c|c|c|}
\hline \multirow[b]{2}{*}{ No } & \multirow{2}{*}{\multicolumn{2}{|c|}{ Variable }} & \multicolumn{2}{|r|}{ Criteria } \\
\hline & & & $\begin{array}{l}\text { Settlement } \\
\text { Unit Area }\end{array}$ & Information \\
\hline 1. & Low & Slums & $8 \mathrm{~m}^{2}$ & $\begin{array}{l}\text { Layout, building density, } \\
\text { inadequate facilities (health, } \\
\text { education, drainage, and } \\
\text { sanitation facilities) }\end{array}$ \\
\hline 2. & Moderate & $\begin{array}{l}\text { Not slum } \\
\text { settlements }\end{array}$ & $126 \mathrm{~m}^{2}$ & $\begin{array}{l}\text { Layout, regular building, and } \\
\text { adequate facilities }\end{array}$ \\
\hline 3. & High & Not a settlement & $1741 \mathrm{~m}^{2}$ & $\begin{array}{l}\text { Strategic layout and building } \\
\text { area }\end{array}$ \\
\hline
\end{tabular}

Source: (Data Processing, 2020)

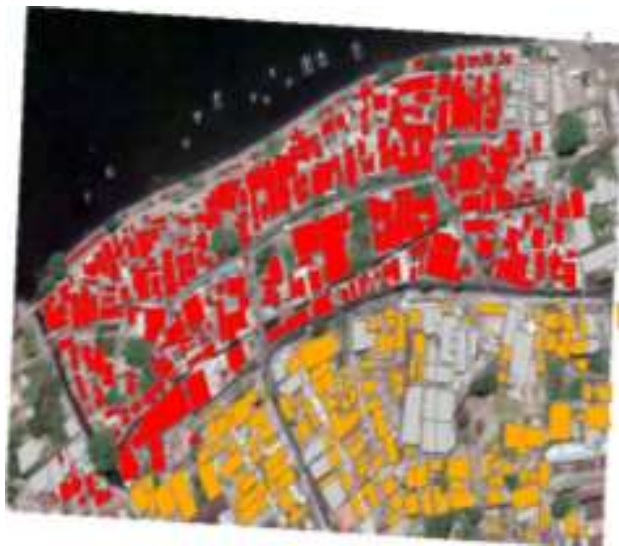

(a)

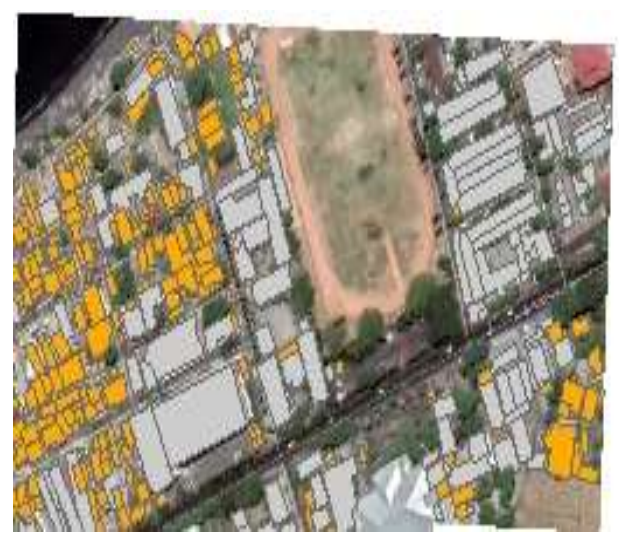

(b)

Fig. 2. Result of Digitazion (a) Slum Settlements and (b) Non-Slum and Non-Settlements 


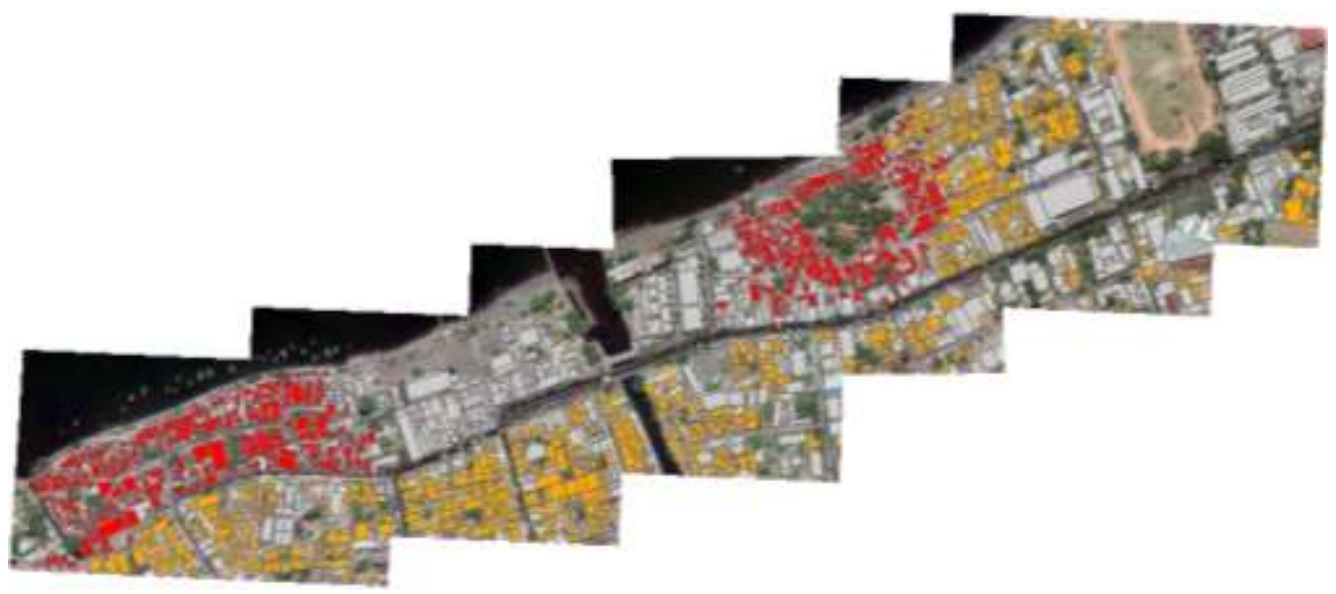

(a)

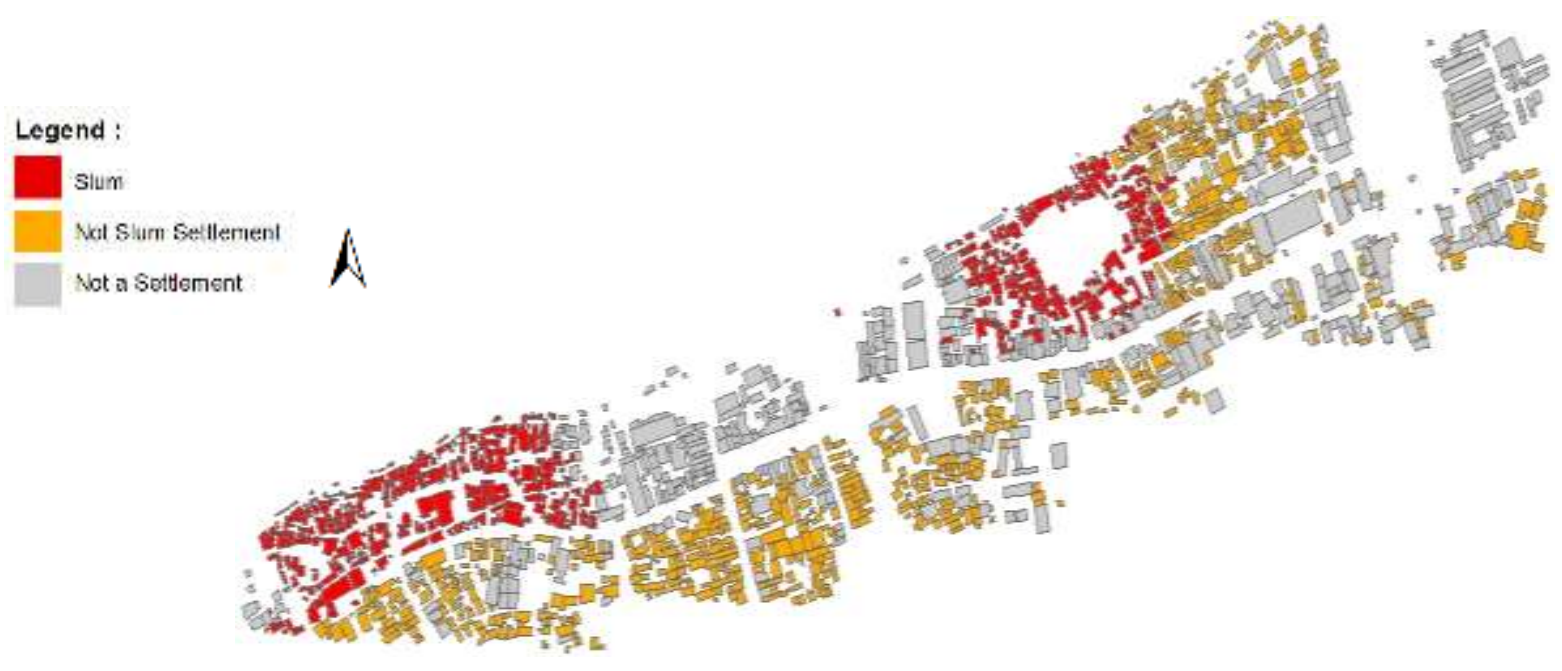

(b)

Fig. 3. Result of Identification Slum on Former Harbor (a) Result with Image and (b) Result without Image

\section{Validation Result}

The validation process is carried out by comparing the results of image interpretation with the field conditions. Based on results, it was found of slum settlements $85 \%$ accurate. The number of buildings is checked in the field based on the parameters in Table 1 . Through the image interpretation key and the year in the image, there is no change in the research area so that the results of the field survey can be ascertained that they still have high validation. The accuracy generated in the image interpretation process by field survey has $85 \%$ accuracy with the study area; most buildings have a permanent structure and have low environmental quality. The existing data is very accurate, but the building area is not always the same as that during the interpretation and field survey. The difference between non-residential buildings, non-slum 1 settlement, and slum settlement can be seen from the building area and shape in the image interpretation, and for the field can see the layout, facilities, population density, and existing building forms in the Ex. Buleleng Pier as a research area. 


\section{Conclusion}

The analysis and validation results show that Remote sensing and geographical detachment system technology integration to analyze and compare this spatiotemporal collection of technology (Quan et al., 2014). Can provide information for identifying slum areas even than $90 \%$ with the image obtained from google earth recording. Meanwhile, when the field survey can be carried out concerning the layout, building conditions, facilities, and the environment around the settlement to facilitate the field survey process by distinguishing slum and non-slum settlement, with this research, it is possible to identify slum settlements in the area former harbor. Besides, the conditions of field survey activities adjust to the area due to the Covid-19 pandemic so that the identification of variables cannot be thoroughly carried out.

\section{References}

Anaperta, Y. M., Octova, A., Maiyudi, R., \& Feldi, D. Y. (2019). Remote sensing application to monitoring mine landuse changing in limestone/dolomite. Journal of Physics: Conference Series, 1387(1). https://doi.org/10.1088/1742-6596/1387/1/012101

BPS Kecamatan Buleleng. (2019). Buleleng District Goverment.

Christiawan, P. I. (2019). Tipe urban sprawl dan eksistensi pertanian di wilayah pinggiran Kota Denpasar. Jurnal Wilayah Dan Lingkungan, 7(2), 79-89.

Dalilah, A., \& Ridwana, R. (2019a). Pemanfaatan Pengindraan Jauh Untuk Identifikasi Permukiman Kumuh di Kota Bandung. Jurnal Ilmu Ilmu Sosial, 5(2), 71. https://doi.org/10.23887/jiis.v5i2.21773

Dalilah, A., \& Ridwana, R. (2019b). Utilization of Remote Sensing to Identify Slum Settlements in Bandung City. Jurnal Regional Science, 5(2), 71. https://doi.org/10.23887/jiis.v5i2.21773

Ekartaji, P., Yunus, H. S., \& Rahardjo, N. (2014). Kajian Kualitas Lingkungan Permukiman di Daerah Pinggir Kota Kasus di Desa Ngestiharjo. Majalah Geografi Indonesia, 8(33), 44.

Hasan, M. Z., Citra, I. P. A., \& Nugraha, A. S. A. (2019). Monitoring Perubahan Garis Pantai Di Kabupaten Jembrana Tahun 1997 - 2018 Menggunakan Modified Difference Water Index ( Mndwi ) Dan Digital Shoreline Analysis System ( DSAS ). Jurnal Pendidikan Geografi Undiksha, 7(3), 93-102.

Ilmy, H. F., \& Budisusanto, Y. (2017). Identifikasi Penentu Prioritas Kriteria Kawasan Permukiman Kumuh Perkotaan Menggunakan Metode AHP (Analytical Hierarcy Process). Jurnal Teknik ITS, 6(1), 19-21. https://doi.org/10.12962/j23373539.v6i1.21510

Indrawati, L., \& Sunarto, H. (2009). Land use in Semarang City using Landsat TM / ETM +. 23(2), 109-123.

Maru, A. C. H., \& Hidayati, I. N. (2016). Pemanfaatan Citra Quickbird dan SIG Untuk Pemetaan tingkat kenyamanan Permukiman Di Kecamatan Semarang Barat dan Kecamatan Semarang Utara. Majalah Geografi Indonesia, 30(1), 1. https://doi.org/10.22146/mgi.15600

Maspiyanti, F., Fanany, M. I., \& Arymurthy, A. M. (2013). Klasifikasi Fase Pertumbuhan Padi Berdasarkan Hiperspektral Dengan Modifikasi Logika Fuzzy. Jurnal Pengindraan Jasuh \& Pengolahan Citra LAPAN, 10(1), 41-48. https://doi.org/http://dx.doi.org/10.12962/j24423998.v9i1.733

Nugraha, A. S.A., Gunawan, T., \& Kamal, M. (2019). Comparison of Land Surface Temperature Derived from Landsat 7 ETM+ and Landsat 8 OLI/TIRS for Drought Monitoring. IOP Conference Series: Earth and Environmental Science, 313(1), 0-10. https://doi.org/10.1088/1755-1315/313/1/012041

Nugraha, A Sediyo Adi. (2019). Pemanfaatan Metode Split-Windows Algorithm ( SWA ) pada Landsat 8 Menggunakan Data Uap Air MODIS Terra (The Application of Split-Windows Algorithm (SWA) Methods on Landsat 8 Using Modis Terra Water Vapor). Geomatika, 25(1), 9-16. https://doi.org/http://doi.org/10.24895/JIG.2019.25-1.877

Nugraha, A Sediyo Adi, \& Atmaja, D. M. (2020). Pemanfaatan Citra Penginderan Jauh MultiTemporal Penggunaan Lahan Di Kabupaten Buleleng ( The Application of Multi-Temporal Remote Sensing Images to Detect Urban Heat Island ( UHI ) for Land use Changes in 
Buleleng District ). Majalah Ilmiah Globe, 22(2), 71-82.

Nugraha, A Sediyo Adi, Gunawan, T., \& Kamal, M. (2019). Downscaling land surface temperature on multi-scale image for drought monitoring. Sixth Geoinformation Science Symposium, November, 6. https://doi.org/10.1117/12.2544550

Quan, B., Liu, X., Lei, S., Guo, T., Song, H., \& Xie, J. (2014). Comparison on urban land use change in China's three terrain ladders. 3rd International Workshop on Earth Observation and Remote Sensing Applications, EORSA 2014 - Proceedings, September, 131-135. https://doi.org/10.1109/EORSA.2014.6927864

Septiani, R., Citra, I. P. A., \& Nugraha, A. S. A. (2019). Perbandingan Metode Supervised Classification dan Unsupervised Classification terhadap Penutup Lahan di Kabupaten Buleleng. Jurnal Geografi : Media Informasi Pengembangan Dan Profesi Kegeografian, 16(2), 90-96. https://doi.org/10.15294/jg.v16i2.19777

Suarjana, I. G. P., Christiawan, P. I., \& Nugraha, A. S. A. (2020). Kondisi Sosial Dan Ekonomi Masyarakat Pengungsi Bencana Erupsi Gunung Agung Desa Ban. 8(April), 33-42.

Suharini, E. (2007). Menemukenali Agihan Permukiman Kumuh di Perkotaan Melalui Intrepetasi Citra Pengindraan Jauh. Jurnal Geografi, 4(2), 77-85. https://doi.org/10.15294/jg.v4i2.100

Sutanto. (1986). Penginderaan Jauh Jilid I.

Sutanto. (1987). Penginderaan Jauh Jilid II. Gadjah Mada University Press. 